\title{
THE FRONTIER ZONE IN BRITAIN: HADRIAN TO GARAGALLA
}

\author{
ANTHony R. BiRley
}

'Frontier' on its own is an inappropriate term for the linear barriers first erected by Hadrian: ${ }^{1}$ the outpost forts are reminders that in Britain the empire did not stop at his Wall or, later, at the Antonine Wall. Lines of forts and towers had already existed in Germany, Britain and elsewhere close to where Hadrian built the palisade in Germany or British Wall. Still, his continuous Annäherungshindernisse were indeed an innovation - although this has been denied: 'Trajan, who was so obviously uninhibited by any defensive notions of the termini imperii in the East, is now believed to have laid the wooden palisades along the line of the Solway Firth.'2 Subsequent investigation has shown that the 'palisade slots' were 'modern land-drain trenches."

Various motives have been suggested for Hadrian's erection of continuous artificial barriers. ${ }^{4}$ As far as Britain is concerned, there had been a serious rebellion at his accession: 'the Britons could not be kept

${ }^{1}$ Cf. remarks by Th. Mommsen, Römische Kaisergeschichte, edited from the transcript of his lectures by B. and A. Demandt (Munich 1992), 299: "Vielfach sind diese großen Befestigungsanlagen [Hadrian's Wall and the Antonine Wall] als die Grenze des römischen Gebietes aufgefaßt worden; das ist gewiß ebenso falsch, wie wenn man in der Anlage der großen deutschen Rheinbefestigungen Wesel und Ehrenbreitstein bei Koblenz etc. die Absicht hätte sehen wollen, das linksrheinische Deutschland aufzugeben."

2 C.R. Whittaker, Frontiers of the Roman Empire. A Social and Economic Study (Baltimore and London 1994), 47, repeated verbatim, id., in Cambridge Ancient History, $11^{2}$ (2000), 304, citing G.D.B. Jones, 'The Solway frontier: interim report', Britannia 13 (1982), 283-298.

${ }^{3}$ D.J. Woolliscroft and G.D.B. Jones, 'Excavations on the Cumberland coast at Silloth, and at Fingland Rigg, 1994', in R.J.A. Wilson and I.D. Caruana, eds., Romans on the Solway (Kendal 2004), 186-194, at 187-190.

${ }^{4}$ A.R. Birley Hadrian the Restless Emperor (London 1997), 133f., stresses the symbolic nature of the new barriers. See also E. Birley, 'Hadrianic Frontier Policy', Carnuntina. Römische Forschungen in Niederösterreich III (Graz/Köln 1965), 25-33, repr., in id., The Roman Army. Papers 1929-1986 (Amsterdam 1988), 12-20; D.J. Breeze and B. Dobson, Hadrian's Wall (London 2000), 25ff.; A.R. Birley, 'Hadrian's travels', in L. de Blois et al., eds., The Representation and Perception of Roman Imperial Power. Proceedings of the Third Workshop of the International Network Impact of Empire (Roman Empire, 200 BC-AD 476), Rome, March 20-23, 2002 (Amsterdam 2003), 425-441, at 435f., $439 f f$. 
under Roman rule' (HA, Vita Hadriani 5.2). Losses were heavy, Fronto later reminded Marcus Aurelius: 'When your grandfather Hadrian held imperial power, how many soldiers were killed by the Jews, how many by the Britons!' (De bello Parthico $2=221$ Van den Hout). Hadrian soon sent a new governor, Q. Pompeius Falco (consul AD 108), from Lower Moesia, where he was legate in $117 .^{5}$ Then reinforcements, 3000 legionaries from Upper Germany and Spain, joined the expeditio Britannica, probably between 119 and $122 .{ }^{6}$ The numbers suggest that there had been losses of this order in the legions; the auxiliaries were also affected. ${ }^{7}$ In 122 Hadrian came in person, murumque... duxit, qui barbaros Romanosque divideret, 'to divide Romans and barbarians' (HA, Vita Hadriani 11.2). ${ }^{8}$ Falco, who had presumably suppressed the revolt, was now replaced by A. Platorius Nepos (consul AD 119), a friend of Hadrian, who had been governing Lower Germany and brought VI Victrix from that province. ${ }^{9}$

Construction lasted for over ten years, with several modifications of plan. The Wall itself was at first 76 miles long, from Newcastle westwards, eventually 80 miles, from Wallsend; there was a western extension of the system southwards along the Cumberland coast for up to 40 miles, with no linear barrier, but fortlets at every mile and two signal-towers between each, matching the Wall's milecastles and turrets. There were also three outpost forts north of the western end, Bewcastle, Birrens and Netherby; two further east, Risingham and High Rochester, are not known to have been occupied under Hadrian. The most powerful single regiment on the Wall, the ala Petriana, the only ala milliaria in Britain, was based first (probably) at Carlisle, then at Stanwix, just across the River Eden. This all suggests that the direction from

${ }^{5}$ PIR ${ }^{2}$ P 602; A.R. Birley, The Roman Government of Britain (Oxford 2005), 114-119.

${ }_{6}^{6}$ ILS 2726; B. Dobson, Die Primipilares (Bonn 1978), no. 117; PIR ${ }^{2}$ P 823.

7 A.R. Birley, 'A new tombstone from Vindolanda', Britannia 29 (1998), 299-306.

${ }^{8}$ The $H A$ calls the Wall murus, but it seems that it was known locally as vallum, as on the souvenir cup naming some forts rigore val(l)i Aeli, 'on the line of the Aelian Wall', Britannia 35 (2004) 344-345; cf. RIB 2034, cited below at n. 42, and the Notitia list of officers per lineam valli (ND Occ. 40.32-49). The flat-bottomed ditch running south of the Wall, with continuous earth mounds on both sides, a Hadrianic addition to the system, was in modern times labelled 'Vallum' incorrectly: see e.g. E. Birley, Research on Hadrian's Wall (Kendal 1961), 116-125; J.C. Bruce, Handbook to the Roman Wall (13th ed. by G.M. Daniels, Newcastle 1978), 30-33 [the 14th ed., by D.J. Breeze, is forthcoming]; Breeze and Dobson, op. cit. (n. 4), esp. 56-59.

${ }_{9}$ Birley 1997, op. cit. (n. 4), 123ff.; Birley 2005, op. cit. (n. 5) 119ff., 284f.; cf. $228 f$. on the uncertain whereabouts and disputed ultimate fate of IX Hispana. 
which the main threat was expected - and very likely, from which the uprising of 117 had been launched - was beyond the western part of the Wall, in south west Scotland. ${ }^{10}$

That area includes Annandale, land of the Anavionenses, who had been subjected to a census, presumably involving conscription, two decades earlier. ${ }^{11}$ The main western Roman road into Scotland, like the M74 motorway between Carlisle and Glasgow, ran parallel to the River Annan. There were significant settlements in this region, notably, close to Birrens, the hill-fort on Burnswark Hill. Because of its shape and prominent position - it is visible from the central sector of the Wall, over 40 kilometres away - and, particularly striking, because of the siege-camps on its north and south sides, Burnswark has often been compared with Masada. The camps, once thought to have been practice-works, surely belonged to a real second century siege, probably under Antoninus. ${ }^{12}$ In medieval and early modern times the AngloScottish border was almost continuously subject to raiding by the 'Border Reivers'; the most troublesome part, the Western March and particularly the 'debatable lands', was not far from Burnswark. ${ }^{13}$

By contrast, beyond the eastern end of the Wall, so it seemed, the Britons were relatively pro-Roman. Yet recent discoveries suggest that enemy attack was expected there as well. The 'Roman equivalent of barbed wire' has been found at three separate sites in Greater Newcastle: pits into which sharp stakes would have been inserted, along the berm between Wall and ditch. ${ }^{14}$ Hence, symbolism or not, and even if the 'over-elaborate and unnecessary structures' of the Hadrianic Limesanlage in Britain can be called 'displacement activity, ${ }^{\prime 5}$ there had been a perceived threat.

\footnotetext{
${ }^{10}$ Birley 1961, op. cit. (n. 8), 'Anatomy', 70-131, 'Outposts', 227-246, and 'Conclusions,' 271-272; Bruce 1978, op. cit. (n. 8), 33-36, (Cumberland coast); Breeze and Dobson 2000, op. cit. (n. 4), 25-83; P. Bidwell, ed., Hadrian's Wall 1989-1999 (Carlisle and Newcastle 1999), 181-7 (Cumberland coast).

${ }_{11}$ The view that there was some Brigantian territory here, repeated in Birley 1997 (n. 4), 130, should be rejected: A.R. Birley, 'The Anavonienses', in N.J. Higham, ed., Archaeology of the Roman Empire. A Tribute to the Life and works of Professor Barri Fones (Oxford 2001), 15-24, at 16ff.

12 D.B. Campbell, 'The Roman siege of Burnswark', Britannia 34 (2003), 19-33.

${ }_{13}$ See G. MacDonald Fraser, The Steel Bonnets. The Story of the Anglo-Scottish Border Reivers (London 1971).

14 'Roman "barbed wire" on Hadrian's Wall', Current Archaeology 195 (2004), 109-113. 532.

${ }^{15}$ J.G. Mann, 'The frontiers of the principate', in $A \mathcal{N} R W 2.1$ (1974), 508-533, at
} 
Of course, Britain cannot be viewed in isolation, and Hadrian created far longer artificial frontiers elsewhere, notably between Rhine and Danube, where work was already in progress before he came to Britain. Dendrochronology now dates to winter 119/120 and summer 120 the felling of oaks for the Upper German palisade, confirming, at last, the $H A$ 's attribution of the work to Hadrian: 'In a great many places where the barbarians are separated (dividuntur) not by rivers but by boundary-lines (limites), he cut them off (separavit) with great stakes driven deep into the ground and fastened together in the manner of a wall-like fence' (Vita Hadriani 12.6). ${ }^{16}$

Platorius Nepos was replaced at latest by 127 by L. Trebius Germanus, about whom little is known. A few years later came Sex. Julius Severus (consul 127), but he, "the foremost among Hadrian's best generals," was soon summoned from Britain to crush the Jewish revolt (Cassius Dio 69.13.2). Cassius Dio's description implies that Britain was a still tough assignment, ferox provincia (Tacitus, Agricola 8.1$).{ }^{17}$

Shortly after Hadrian's death, his Wall was given up and southern Scotland re-occupied: "[Antoninus] ... conquered the Britons through the legate Lollius Urbicus, another wall, of turf, being built, after the removal of the barbarians" (HA, Vita Antonini Pii 5.4). The new Wall was built where Agricola had noted a possible in ipsa Britannia terminus (Agricola 23). Urbicus was in Britain in 139 and Antoninus took his second imperatorial acclamation by 1 August $142 .{ }^{18}$ Pausanias also refers to a British conflict: Pius never voluntarily waged war, but "confiscated a large part of the territory of the Brigantes in Britain because they invaded the Genunian district, of which the inhabitants were subject to Rome" (8.43). No 'Genunian' district is known in Britain: Pausanias surely confused two episodes, Urbicus' war and otherwise unrecorded fighting in Raetia between the Brigantii and their neighbours the Genauni. ${ }^{19}$ This passage throws no light on Pius' motives for reoccupying southern Scotland.

${ }^{16}$ E. Schallmayer, 'Der Limes, Marköbel und Kaiser Hadrian. Neue wissenschaftliche Erkenntnisse zum Obergermanischen-Raetischen Limes und ihre öffentlichkeitswirksame Präsentation', Denkmalpflege $\&$ Kulturgeschichte 2/2003 (Landesamt für Denkmalpflege Hessen, Wiesbaden), 12-21, at 14-16.

17 Birley 2005, op. cit. (n. 5) 125-129 (Trebius); 129-132 (Severus). The limited evidence for Hadrian's last years need not be discussed here.

${ }_{18}$ Birley 2005, op. cit. (n. 5), 136ff. Imp. II: RMD 264, 394.

19 Thus, convincingly, J.G.F. Hind, 'The "Genunian" part of Britain', Britannia 8 (1977), 229-234; see also A.L.F. Rivet and C. Smith, The Place-Names of Roman Britain (London 1979), 47; W.S. Hanson and G.S. Maxwell, Rome's North West Frontier. The Antonine Wall (Edinburgh 1983), 62f. 
The reversal of policy is remarkable. Gillam offered two explanations: "In a sense Hadrian's Wall had been a strategical failure, because the potential enemies to north and north west were out of its reach...Tactically the Wall had been so complete a success that it was decided to move the system, with modifications, bodily northwards." ${ }^{20}$ Equally, one may suspect political motives: Antoninus offering a 'sop' to the viri militares, disgusted by Hadrian's retrenchment. ${ }^{21}$ Besides, like Claudius a century earlier, an emperor with no military experience needed military prestige. ${ }^{22}$ A casus belli was perhaps provided by an uprising in south west Scotland, leading to the siege of Burnswark mentioned above. At all events, most of the now obsolete installations of Hadrian's Wall were dismantled, and garrisons moved forward. The new Wall, being of turf and only half the length of Hadrian's Wall, was much cheaper. But it also had outposts: Camelon, Ardoch, Strageath and, at the confluence of the Almond with the Tay, Bertha, all previously occupied in the Flavian period..$^{23}$

It used to be thought that the Antonine Wall had two separate occupation periods. Hodgson has now argued convincingly that it was abandoned for good $c .158 .{ }^{24}$ Hadrian's Wall was being rebuilt that year: leg(io) VI V(ictrix) p(ia) f(idelis) ref(ecit) Ter(tullo) et Sac(erdote) co(n)s(ulibus). ${ }^{25}$ Was rebuilding necessary because the supposedly superfluous Wall had been a convenient source of stone for new accommodation in nearby

${ }^{20}$ J.P. Gillam, 'Roman and native AD 122-197', in I.A. Richmond, ed., Roman and Native in North Britain (Edinburgh 1961), 60-89, at 66f.

${ }^{21}$ A.R. Birley, 'Roman frontiers and Roman frontier policy: some reflections on Roman imperialism', Transactions of the Architectural and Archaeological Society of Durham $\mathfrak{E}^{\circ}$ Northumberland 3 (1974), 13-25, at $17 f$.

${ }^{22}$ Thus D.J. Breeze, 'Why did the Romans fail to conquer Scotland?,' PSAS 118 (1988), 3-22, at 18; repr. in id. and B. Dobson, Officers and Frontiers (Stuttgart 1993), $365-384$, at 380 .

${ }^{23}$ D.J. Breeze, The Northern Frontiers of Roman Britain (London 1982), 97ff.; Hanson and Maxwell 1983, op. cit. (n. 19), 59ff.; 101ff., 159ff. (outposts). It used to be supposed that both Walls were occupied simultaneously: e.g. in the 19th century by Mommsen (n. 1), 299: 'Es war eine doppelte Enceinte'; and still by S.S. Frere, Britannia. A History of Roman Britain (London 1967), 156ff.; later, following B.R. Hartley, 'The Roman occupation of Scotland: the evidence of samian ware', Britannia 3 (1972), $1-55$, at $15 \mathrm{ff}$. ., Frere retracted this view, op. cit. (London 19873), $131 \mathrm{ff}$. Whittaker 1994, op. cit. (n. 2), 47f., and 2000, 304, it is strange, still propagates the idea that both Walls were held simultaneously, which he even writes that 'we are increasingly coming to believe'.

${ }^{24}$ N. Hodgson, 'Were there two Antonine occupations of Scotland?', Britannia 26 (1995), 24-49; his case is accepted by Breeze and Dobson 2000, op. cit. (n. 4), 125ff., $129 \mathrm{ff}$.

${ }^{25}$ RIB 1389, near Heddon. 
forts ${ }^{26}$ The governor in 158 was Cn. Julius Verus, previously legate of Lower Germany. ${ }^{27} \mathrm{He}$ is attested by several inscriptions, including a dedication at Newcastle by the vexil(l)atio leg. II Aug. et leg. VI Vic. et leg. XX V.V. con(t)ributi ex(ercitibus) Ger(manicis) duobus sub Iulio Vero leg. Aug. pr. $p r$. The interpretation is uncertain: men from the British legions about to go to Germany; men previously sent to Germany returning; the British legions being reinforced by men from the German armies? ${ }^{28}$ By apparent paradox, just when the outer limes in Britain was abandoned, one was being created in Upper Germany: the motives for both measures remain unclear. ${ }^{29}$ The restored Hadrianic frontier line again had outposts, indeed more than before: the three at the western end were matched by three more along Dere Street, the old north road into Scotland, Risingham, High Rochester and Newstead. ${ }^{30}$ This advanced zone was called a praetentura or praetensio. ${ }^{31}$

Julius Verus' successor is known only from the Colchester diploma, datable to 24 June 160 , on which his name is incomplete, perhaps [M. Pisib] anus Lep[idus], consul 159. ${ }^{32}$ The commander of cohors I fida Vardullorum on the diploma, [...] Verus, is surely Trebius Verus, under whom the Vardulli dedicated an altar to Neptune at Castlecary on the Antonine Wall. ${ }^{33}$ Perhaps they made a vow to the sea-god on the eve of withdrawal by ship, some two years before the diploma was issued: Trebius could have continued in post, at a new base.

The first governor under Marcus Aurelius, M. Statius Priscus (consul ordinarius 159), who had won victories in Dacia just before his consul-

${ }^{26}$ Thus M.G. Jarrett and J.C. Mann, 'Britain from Agricola to Gallienus', Bonner Fahrbücher 170 (1970), 178-210, at 188.

${ }^{27} \mathrm{He}$ was in Britain by 27 February $158, R M D \mathrm{~V}$ 419, and had building done at Birrens that year, RIB 2110; Birley 2005, op. cit. (n. 5), 145-149.

${ }^{28}$ RIB 1322+add.; Birley 2005, op. cit. (n. 5), 146 n. 41, sumnmarises the arguments. Add G. Alföldy, 'Die lineare Grenzziehung des vorderen Limes in Obergermanien und die Statthalterschaft des Gaius Popilius Carus Pedo', in E. Schallmayer, ed., Limes Imperii Romani. Beiträge zum Fachkolloquium "Weltkulturerbe Limes" November 2001 in Lich-Arnsburg (Bad Homburg v.d.H. 2004), 7-20.

${ }^{29}$ See Alföldy 2004, op. cit. (n. 28) on the 'vordere Limes'; for Britain, cf. Breeze 1988, op. cit. (n. 22), 18 (= 380); Breeze and Dobson 2000, op. cit. (n. 4), 130f. Had there been an uprising in Britain, with destruction at Birrens and a siege of Burnswark? Cf. above and n. 12.

${ }_{30}$ Breeze and Dobson 2000, op. cit. (n. 4), 132f.

${ }^{31}$ See M.P. Speidel, 'The Risingham praetensio', Britannia 29 (1998) 356-359, improving RIB 1152, Corbridge and 1229, Risingham.

${ }_{32}$ CIL XVI $130=$ RIB II 2401.12, as interpreted by Birley 2005, op. cit. (n. 5), $150-151$.

${ }^{33}$ RIB 2149. 
ship, was evidently appointed in 161 , but after hardly a year was summoned to deal with an eastern crisis. ${ }^{34}$ This recalls Hadrian's sending Julius Severus to Judaea. Priscus may have been intended to deal with 'the threat of a British war'; instead, a new governor got the task: "Calpurnius Agricola was sent against the Britons" (HA, Vita Marci Antonini Philos. 8.7-8). From the context the date was autumn 161 or early 162. Polyaenus, whose work was dedicated to the emperors in 162 , mentions "the Britons being defeated" (Strategemata 6, pr.). Calpurnius Agricola is attested by several inscriptions on or near Hadrian's Wall and in its hinterland. ${ }^{35}$

The HA refers again to 'the threat of a British war' under Marcus, the context this time being the early 170s (Vita Marci Antonini Philos. 22.1). Three more governors are known in this reign. Q. Antistius Adventus (consul c. 167), recorded in Britain only by an inscription in the Wall hinterland, perhaps served c. 172-175: his career, well known from other evidence, included service in the Parthian War, a special command in the Marcomannic War, then the governorship of Lower Germany. ${ }^{36} \mathrm{He}$ or his successor had a major logistical undertaking: following the armistice in 175, the Sarmatians surrendered 8000 men, of whom 5,500 were sent to Britain (Cassius Dio 71.16.2). Did Britain need reinforcements - or was it a just convenient place to station potential trouble-makers? The next governor had held several commands during the Marcomannic War. His name is missing on the altar he dedicated at Mainz on appointment to Britain, the only evidence for his governorship. He was presumably called Caerellius, as were his children. ${ }^{37}$ He cannot have served long. Several diplomas from a constitutio of 23 March 178 show that the governor that day was Ulpius Marcellus, who had probably arrived the previous year. ${ }^{38}$

Marcellus, who had perhaps governed Lower Pannonia c. 175, was already attested in Britain by three inscriptions from Hadrian's Wall, two at Chesters as legate of a single emperor, the other, at Benwell, under two emperors - and by an excerpt from Cassius Dio: "[Commodus] had wars against the barbarians beyond Dacia... But

\footnotetext{
${ }^{34}$ Birley 2005, op. cit. (n. 5), 151-155.

35 Birley 2005, op. cit. (n. 5), 155-157.

${ }^{36}$ RIB 1083, Lanchester; Birley 2005, op. cit. (n. 5), 157-161.

37 CIL XIII 6806, Mainz, reinterpreted by K. Dietz, 'Zur Verwaltungsgeschichte Obergermaniens und Rätiens unter Mark Aurel', Chiron 19 (1989), 407-447; Birley 2005 (n. 5), 161-162.

${ }^{38}$ RMD III 184; IV 293-4. Other, fragmentary examples are still unpublished.
} 
the greatest war was the British one. The peoples in the island crossed the wall that separated them and the Roman legions, did much harm,

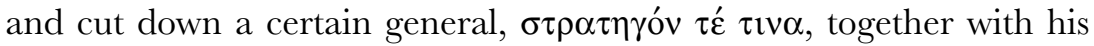
soldiers. Commodus, being alarmed, sent Marcellus Ulpius against them" (72[73].8.1-2). An account of Marcellus' stern character and odd practices concludes: "Marcellus, being such a man as this, did the barbarians in Britain grievous damage; later, when about to be put to death because of his special excellence, he was nevertheless spared" (72.8.6). Cassius Dio's usage suggested that the $\sigma \tau \rho \alpha \tau \eta \gamma$ ó $\varsigma$ killed in the

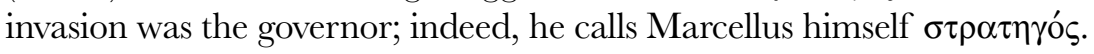
Further, as Marcellus was 'sent against the barbarians' by Commodus as sole emperor, it appeared that his governorship did not begin until after Marcus' death. Hence the Benwell inscription was taken to refer to a second Ulpius Marcellus. The diplomas have exploded this theory: hence, either the $\sigma \tau \rho \alpha \tau \eta \gamma$ ó killed in the invasion was only a legionary legate, or Marcellus governed the same province twice, which is almost unparalleled. ${ }^{39}$

It can surely be assumed that "the Wall separating the invaders from the Roman legions" was that of Hadrian. There was destruction in the later second century, perhaps during this invasion, at Haltonchesters, close to where Dere Street, the Roman road to Scotland, goes through the Wall, and its eastern neighbour Rudchester; also at Corbridge, where Dere Street meets the Stanegate, two miles south of the Wall. ${ }^{40}$ Victory was claimed in 184, when Commodus became imperator VII and Britannicus maximus. ${ }^{41}$ A Carlisle dedication commemorating the defeat "of barbarians" may refer to this war. It begins dei Herc[ulis... in]/victi con[...]/tibus, perhaps reflecting Commodus' Hercules cult. ${ }^{42}$ Further, an altar set up about six kilometres north west of Carlisle by L. Junius Victorinus $\mathrm{Fl}[\mathrm{av}(\mathrm{ius})]$ Caelianus, leg. Aug. of VI Victrix, ob res trans vallum

39 Birley 2005, op. cit. (n. 5), 162-170, accepting that the second Marcellus postulated in A.R. Birley, The Fasti of Roman Britain (Oxford 1981), 140ff., 164ff., did not exist.

${ }_{40}$ Breeze and Dobson 2000, op. cit. (n. 4), 134. But Frere 1987, op. cit. (n. 23), 147f., is sceptical about the dating, preferring destruction $c .197$ (see below).

${ }^{41}$ ILS 393-395; BMC IV Antoninus Pius to Commodus, pp. CLVIII, CLXXIV, CLXXX.

${ }^{42}$ RIB 946. J.C.N. Coulston and E.J. Phillips, Corpus Signorum Imperï Romani I 6 (Oxford 1988), no. 474, regard a Commodan date as 'a strong possibility'. R.S.O. Tomlin and M.W.C. Hassall, 'Inscriptions', Britannia 30 (1999), 375-386, at 384ff., assign it to 192. Commodus' Hercules-obsession peaked in 191-192: O.J. Hekster, Commodus. An Emperor at the Crossroads (Amsterdam 2002), 106-111; 117-120. But Hercules is already on a coin of early 184: BMC IV, Commodus, nos. 505, 525. 
prospere gestas, must be dated after the abandonment of the Antonine Wall and before the division of Britain, when the legate of VI Victrix became governor of Inferior. As Victorinus was leg. Aug. not leg. Augg. he surely served under either Antoninus Pius, c. 158-161, or Marcus Aurelius as sole emperor, 169-176, or Commodus. ${ }^{43}$

If Marcellus served uninterruptedly, his governorship was the longest since that of Julius Agricola a century earlier. Both fought northern peoples successfully. But unlike Agricola, who handed over the province to his successor quietam tutamque (Agricola 40.3), Marcellus, evidently recalled soon after his victory, left Britain in turmoil. Perhaps in reaction to his harsh methods, the army became mutinous. A fragment of Cassius Dio describes what may be the first outbreak: "The soldiers in Britain chose Priscus, a legionary legate, i $\pi \circ \sigma \tau \rho \alpha ́ \tau \eta \gamma o v$, as emperor; but he declined, saying: "I am no more emperor than you are soldiers", (72(73).9.2a = Petr. Patr., Exc. Vat. 122). This was clearly in 184, for the HA, although not naming Priscus, surely refers to this episode: "Commodus was called Britannicus by flatterers when the Britons even wanted to choose another emperor against him" (Vita Commodi 8.4). Priscus was no doubt dismissed. Without making the connection, the HA had already mentioned that the Guard Prefect Perennis "put men of equestrian rank in command of the soldiers in the British war, removing the senators," and that this measure caused his downfall: "when this was made known through representatives of the army (per legatos exercitus), he was suddenly declared a public enemy and given to the soldiers to be lynched" (Vita Commodi 6.2). Cassius Dio's version differs slightly: "Those ${ }^{45}$ in Britain, after being rebuked for mutinous conduct (they did not quieten down until Pertinax quelled them), selected 1500 javelin-men and sent them to Italy" (72 (73). $\left.2^{2}-4\right)$. When Commodus met them near Rome, they denounced Perennis for plotting to make his son emperor, and he was handed over to be lynched. It seems hardly credible that the 1500 legionaries were really sent from Britain to denounce Perennis. Perhaps they were part of a task force rounding up deserters, whose activities had reached alarming proportions in Gaul

${ }^{43}$ RIB 2034; Birley 2005, op. cit. (n. 5), 263 f.

44 Its position in the Excerpta dates the passage to between 177 and 188-189.

45 P.A. Brunt, 'The fall of Perennis: Dio-Xiphilinus 72.9.2', Classical Quarterly 23

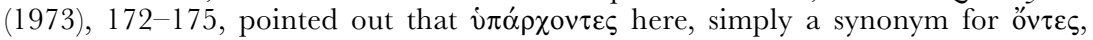
has been mistranslated as 'lieutenants', i.e. legionary legates, as in the Loeb edition (vol. IX p. 89), influenced by HA, Vita Commodi 6.2-but there legatos exercitus means the 1500 "javelin-men" as "representatives of the army." 
and Spain and may even have got as far as Rome. ${ }^{46}$ However this may be, Perennis' fall can be dated to 185, the year 'when [Commodus] was called Felix after he had killed Perennis' (HA, Vita Commodi 8.1). ${ }^{47}$

With neither governor nor legionary legates in post, the only senator left in Britain was the iuridicus, identifiable as M. Antius Crescens Calpurnianus: he also served as vice leg(ati), surely at this time, no doubt until the arrival of the new governor, Pertinax, later in 185, after the fall of Perennis. ${ }^{48}$ The trouble continued: "The soldiers wanted to make any man whatever emperor, especially Pertinax himself ...He was almost killed in a mutiny of a legion... and sought to be excused from his legateship, saying that the legions were hostile to him because he had imposed discipline." (HA, Vita Pertinacis 3.5-6, 8-10, 4.1; cf. Cassius Dio 72[73].9.2²; 73[74].5.1). Pertinax probably served only until c. 187. ${ }^{49}$ His successor, who is not named (HA, Vita Pertinacis 4.1, accepto successore), was probably not the next known governor, D. Clodius Albinus, installed at latest in 192.

Albinus was named Caesar by Severus in spring 193, and remained in Britain until late 195, when the two fell out: Albinus moved to the continent and proclaimed himself Augustus. ${ }^{50}$ The decisive battle at Lugdunum in February 197 involved 150,000 men (Cassius Dio 75[76].6.1). ${ }^{51}$ Albinus must have brought large numbers of troops from Britain. Before leaving he evidently exacted promises of good behaviour from the northern peoples - who did not keep them: Virius Lupus, Severus' new governor, "was forced to buy peace from the Maeatae for a large sum, because the Caledonians did not abide by their promises

${ }^{46}$ On the bellum desertorum (HA, Vita Commodi 16.2; cf. HA, Vita Pescennii Nigri 3.3), see the literature in G. Alföldy's commentary on CIL VI 41127, Rome, honouring a senator who commanded a task-force, perhaps in this war, possibly even identical with the legate Priscus. See also M. Zimmermann, Kaiser und Ereignis: Studien zum Geschichtswerk Herodians (Munich 1999), 85-112, for the fictitious nature of Herodian's account. L. Artorius Castus, prefect of VI Victrix, who had a special command over vexillations from two British legions, ILS 2770+add., is often associated with these events. But, as shown by X. Loriot, 'Un mythe historiographique: l'expédition de L. Artorius Castus contre les Armoricains', BSNAF (1997), 85-87, the command was adversus Arme[nio]s (not Arm[orico]s), probably under Caracalla or Severus Alexander.

${ }^{47}$ A. Stein, RE 6Al (1936), 955; F. Grosso, La lotta politica al tempo di Commodo (Rome 1964), 185ff.

${ }^{48}$ CIL VI 1336 = ILS 1151 = CIL VI 41777; on the dating, Birley 2005, op. cit. (n. 5), 170-171 (where some minor details of the inscription are incorrectly given).

${ }^{49}$ Birley 2005, op. cit. (n. 5), 172-174.

${ }^{50}$ Birley 2005, op. cit. (n. 5), 174-180.

${ }^{51}$ This is the total for both sides together: A.J. Graham, 'The numbers at Lugdunum', Historia 27 (1968), 625-630. 
and were preparing to help the Maeatae, and because Severus was devoting himself to the Parthian war; and he got back a few captives" (Cassius Dio 75.5.4). The passage clearly attests Roman weakness and implies that the Maeatae had penetrated the province. Had the destruction detected at Haltonchesters, Rudchester and Corbridge (and several points further south) after all have been caused then, rather than in the early $180 \mathrm{~s}^{32}$

Herodian states that Britain was divided into two provinces immediately after Albinus' defeat (3.8.2). This conflicts with all the other evidence and must be dismissed as a mistake (one of many by this author). The division took place under Caracalla, probably in $213 .^{53}$ Lupus is also attested as governor by the Digest (28.6.2.4: of Britain, not 'Lower Britain'), and by inscriptions, two at Pennine forts, restoring buildings, one datable to 197, and by another at Corbridge. ${ }^{54}$

The passage from Cassius Dio cited above is the earliest evidence for the northern peoples being labelled 'Caledonii and Maeatae'. He elaborates later: "There are two very large peoples of the Britons [sc. of 'the hostile part', 76[77].12.5], Caledonii and Maeatae, and the names of the others have so to speak been merged into them. The Maeatae live next to the cross-wall which divides the island in two, and the Caledonians beyond them." (76[77].12.1). Although Tacitus did not refer to the Caledonii, but to 'the inhabitants of Caledonia' (Agricola 11.2, 25.3), meaning Scotland north of the Forth-Clyde line

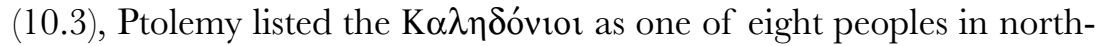
ern Scotland (Geographia 2.3.8-9). Clearly, before the end of the second century eight had 'merged' into two. For this phenomenon one may compare the Alamanni, first attested in $213 .{ }^{55}$ By the late third and early

52 A.R. Birley, 'Virius Lupus', Archaeologia Aeliana, 4th series 50 (1972), 179-189; Frere 1987, op. cit. (n. 23), 155ff., 176f., n. 4.

${ }^{53}$ Birley 2005, op. cit. (n. 5), 333-336. See Zimmermann 1999, op. cit. (n. 46) for numerous examples of Herodian's errors. On the division of Britain he comments, at 202: 'Diese von Caracalla veranlaßte Maßnahme wird nämlich kürzerhand Septimius Severus zugeschrieben, da eine derartige Regelung nicht in das Bild paßt, das Herodian von Caracalla zeichnet.'

${ }^{54}$ Birley 2005, op. cit. (n. 5), 183-186.

${ }^{55}$ The communis opinio is that the Alamanni only emerged in the later third century, their naming in excerpts and summaries of Dio being supposedly Byzantine glosses. But B. Bleckmann, 'Die Alamannen im 3. Jahrhundert: althistorische Bemerkungen zur Ersterwähnungen und zur Ethnogenese', MH 59 (2002), 145-171, shows that this is mistaken. J.C. Mann, 'The northern frontier after AD 369', Glasgow Archaeological fournal 3 (1974), 34-42, at 41, compares the fusion into great confederations of continental peoples faced with Roman power with "the rise of the Pictish kingdom,... clearly a 
fourth centuries the northern Britons are Picti (Panegyrici Latini Veteres 8[5].11.4) or Caledones aliique Picti (6[7].7.2); and the Laterculus Veronensis begins its list of gentes barbarae, quae pullulaverunt sub imperatoribus, with Scoti, Picti, Calidoni (13.1-4). In the post-Roman period there were two Pictish regions, north and south of the Mounth, the earlier existence of which is implied by Ammianus Marcellinus, writing in the 390s: "the Picti are divided into two nations, Dicalydones and Verturiones" (27.8.4). The Dicalydones are the Caledonii; the name Verturiones is preserved in Gaelic form as the Fortrenn district. At first sight the Maeatae have disappeared, but in Fortrenn, near Stirling, the name survives as Dumyat, dun, fortress, of the Maeatae, and Myot Hill. ${ }^{56}$

There may be an earlier record of the Picts. At or near Corbridge Q. Calpurnius Concessinius, prefect of cavalry, dedicated an altar, at latest in the third century, 'after slaughtering a band of Cori[t]onototae'. ${ }^{57}$ The reading in a drawing of the lost stone, Corionototarum in the genitive, can be emended to Cori[t]onototarum. This could represent Cruithen-túatha, the Q-Celtic name for the Picts, with the addition of -tatae, for tuath(a) 'people(s)'. ${ }^{58}$ The apparent use of Q-Celtic, confined to Ireland, at such an early date, seems odd, to be sure. But it has been argued convincingly that the Scoti of Dal Riada did not first arrive - from Ireland - in the fifth century, but had been there since the first millennium Ba. Some of them may have joined a Pictish raid. ${ }^{59}$

The next governor after Lupus, C. Valerius Pudens, is recorded only at a Pennine fort, rebuilding a barrack in 205. ${ }^{60}$ Pudens' successor L. Alfenus Senecio is recorded not only in the Pennines but on the Wall and at the outpost of Risingham. It may be inferred that there was still no intention to move into Scotland again. An inscription from

reaction to the continuing presence of Rome to the south, to her continuing control of southern Scotland and to her occasional interventions north of the Highland Line."

${ }_{56}$ Rivet and Smith 1979, op. cit. (n. 19), 496f. (Verturiones), 404 (Maeatae); the Maeatae also recur as Miathi in Adamnan, Vita Columbae 1.8. On the Picts, K. Forsyth, Language in Pictland: the case against 'non-Indo-European Pictish.' Studia Hameliana 2 (Utrecht 1997), has convincingly shown that they were speakers of a variety of P-Celtic, which she calls 'Pritenic'; for a helpful survey see S.M. Foster, Picts, Gaels and Scots (London $\left.2004^{2}\right)$.

${ }^{57}$ RIB 1142.

${ }^{58}$ H.M. Chadwick, Early Scotland (Cambridge 1949), 71f., 139; cf. for another interpretation Rivet and Smith 1979, op. cit. (n. 19), 322, $317 \mathrm{ff}$.

${ }^{59}$ E. Campbell, 'Were the Scots Irish?', Antiquity 75 (2001), 285-292, supported by Foster 2004, op. cit. (n. 56), 9f., with further bibliography.

${ }^{60}$ Birley 2005, op. cit. (n. 5), 186-188. 
Benwell dedicated under him to the "Victory of the Emperors," hints that he was one of those "others through whom Severus was winning victories in Britain" while struggling for two years to defeat a bandit in Italy (Cassius Dio 76 [77].10.6). ${ }^{61}$ A legate of legio II Augusta who dedicated to Victoria Aug. at Corbridge, L. Julius Julianus, served either under Senecio or during the Severan expedition, ${ }^{62}$ which lasted from $208-211 .^{63}$

The Greek writers claim to know Severus' motives. Cassius Dio says it was because "he wanted to get his sons away from Rome, so that they would behave better under military discipline" (76[77].11.1). Herodian is even more specific. Just when Severus was becoming displeased at his sons' behaviour, 'the governor of Britain' appealed for assistance, welcome news for Severus, a lover of glory, who wanted to add a victory against the Britons to those won in east and north (3.14.12). The governor's appeal was probably invented, ${ }^{64}$ although there was no doubt warfare, as Cassius Dio's report about 'winning victories in Britain through others' shows. Herodian's remarks about Severus' love of glory are also plausible enough.

Cassius Dio is unequivocal about Severus' intentions: "wishing to subjugate the whole of it [the island], he invaded Caledonia" (76[77].13.1). Severus was accompanied by Julia Domna, Caracalla and Geta, and the Guard Prefect Aemilius Papinianus - with, no doubt, some of the Rome cohorts, part at least of the new legion II Parthica, and other troops. ${ }^{65}$ Sex. Varius Marcellus, husband of Julia Domna's niece Soaemias, served as procurator of Britain at this time, and Marcellus' father-inlaw, C. Julius Avitus Alexianus, was one of the emperors' comites. The classis Britannica was probably strengthened by detachments from the Rhine and Danube fleets. ${ }^{66}$ Coins of 208, with Severus mounted and a bridge, presumably refer to the expedition; an As or small bronze

${ }^{61}$ Birley 2005, op. cit. (n. 5), 188-192.

62 Birley 2005, op. cit. (n. 5), 266.

63 The sources are cited in extenso in Birley 2005, op. cit. (n. 5), 198-202.

64 See Birley 1972, op. cit. (n. 52), 186ff., for parallel (invented) 'appeals' from governors in Herodian.

65 For a centaur-standard assignable to this legion, found near Middleham in North Yorkshire: M.V. Taylor, 'The Sidmouth bronze: legionary standard or tripod?', Antf 24 (1944), 22-26, at 24f.; noted by N. Reed, 'The Scottish campaigns of Septimius Severus', PSAS 107 (1975-1976), 92-102, at 96 and n. 6.

${ }_{66}$ Birley 2005, op. cit. (n. 5), 313f. (Marcellus); 225f. (Papinian, comites Augg.); 320 (fleet, on CIL VI 1643). 
medallion of Caracalla issued in 209 has a pontoon-bridge with the legend TRAIECTVS. ${ }^{67}$

In preparation for the advance the fort at South Shields at the mouth of the Tyne was converted into a massive supply base and that at Cramond on the Forth was reoccupied. At Corbridge an altar was set up by the [pr]aep(ositus) cur[am] agens horreorum tempo [r]e expeditionis felicissi(mae) Brittanic(ae), surely at this time. ${ }^{68}$ In a curious development at Vindolanda, the existing fort was dismantled and its entire area, so it seems, filled with, by calculation, up to 200 round stone huts, c. $5 \mathrm{~m}$. or more in diameter. A new fort with normal barracks but an otherwise unusual plan was constructed at right angles to the old one. It is a matter of speculation who occupied the huts. The date is clearly Severan; both new fort and round huts were short-lived, being replaced by a normal fort, built over the foundations of the demolished huts, in the reign of Caracalla. ${ }^{69}$

Marching-camps chart the progress of the expedition into north east Scotland, ${ }^{70}$ as does the large base at Carpow on the south bank of the Tay, with main buildings of stone. ${ }^{71}$ Over 200 stamped tiles show the involvement in its construction of the legion $V I V i c($ trix $) B$ (ritannica) p(ia)

${ }^{67} B M C$ V, Severus 269§; 351 no. 857 (AD 208); 353† (AD 209); A.S. Robertson, 'The bridges on Severan coins of $\mathrm{AD} 208$ and 209', in W.S. Hanson and L.J.F. Keppie, eds., Roman Frontier Studies 1979 (Oxford 1981), 131-140, correcting the use of numismatic evidence by Reed 1975-1976, op. cit. (n. 65).

${ }^{68}$ South Shields: P. Bidwell and S. Speak, Excavations at South Shields Roman Fort I (Newcastle 1994), 20ff. Cramond: A. and V. Rae, 'The Roman fort at Cramond, Edinburgh: excavations 1954-1966', Britannia 5 (1974), 163-224. Corbridge: the Severan date of Site 11, the unfinished storehouse, forum or legionary headquarters building, is accepted by Frere 1987 (n. 23), 159, but rejected by G. Simpson, 'Haltwhistle Burn, Corstopitum and the Antonine Wall: a reconsideration', Britannia 5 (1974), 317-339, at $327 f f$; she is followed by M.J. Bishop and J.N. Dore, Corbridge. Excavations of the Roman Fort and Town, 1947-1980 (London 1989), 139. Altar: RIB 1143; new granaries were built under Severus, RIB 1151, datable only within the period 198-209.

${ }^{69}$ J. Blake, Vindolanda Excavations 2000: The Southern Defences of Stone Fort Two, with the Circular Huts and Other Features (Greenhead 2001), 7ff.; Andrew Birley, Vindolanda Report 2003, The Excavations of 2001 and 2002, 1 (Bardon Mill 2003), 52ff. Lack of space prevents further discussion of the huts, for which no parallels within Roman forts can be found.

${ }^{70}$ J.K.S. St Joseph, 'Air reconnaissance in Britain, 1965-1968', fRS 59 (1969), 104-128, at 114ff.; id., 'Air reconnaissance in Roman Britain', JRS 63 (1973), 214-246, at $230 \mathrm{ff}$.

${ }^{71}$ R.E. Birley, 'The Roman legionary fortress at Carpow, Perthshire', Scottish Historical Review 42 (1963), 126-134; id., 'Excavations of a Roman fortress at Carpow, Perthshire, 1961-1962', PSAS 96 (1962-1963), 184-207; J.N. Dore and J.J. Wilkes, 'Excavations directed by J.D. Leach and J.J. Wilkes on the site of a Roman fortress at Carpow, Perthshire, 1964-1979', ibid. 129 (1999), 481-575. 
f(idelis). ${ }^{72}$ B (ritannica) echoes the emperors' title Britannicus maximus, probably assumed on 31 March $210,{ }^{73}$ following the conclusion of a treaty with the Caledonians (Cassius Dio 76.14.3, 16.5) - which they then broke (76.15.1-2). The emblems of II Augusta are carved on a very fragmentary monumental inscription from the porta praetoria; the six surviving letters probably formed part of Caracalla's titulature, but not necessarily after he had become sole emperor. ${ }^{74}$

The descriptions of the northern peoples in Cassius Dio-Xiphilinus (77 [77].12.1-5) and Herodian (3.14.6-8), stressing their nakedness and other primitive features, are largely topoi about barbarians. ${ }^{75}$ Both writers stress that the Romans failed to bring their opponents, who used guerrilla tactics, to pitched battle. The Carpow fortress confirms Cassius Dio's statement that Severus intended to subjugate the whole island (76[77].13.1) $\cdot{ }^{76}$ His persistence, pressing on 'to the end of the island', carried in a covered litter because of his gout, impressed Cassius Dio (76[77].13.4), and evidently Mommsen as well, whose baffling judgement on Severus' expedition, "vielleicht die patriotischte, vernünftigste Unternehmung der Kaiserzeit," is surely excessive. ${ }^{77}$ In any case, when Severus died, at York on 4 February 211, his sons abandoned the conquests and returned to Rome (Cassius Dio 76[77].15.1-3; 77[78].1.1-6; Herodian 3.15.4-7), evidently reaching it within two months. ${ }^{78}$

${ }^{72}$ RIB II 2460.71-74; one example has been found at the legion's base, York, ibid. 75 .

${ }^{73}$ M. Heil, 'On the date of the title Britannicus Maximus of Septimius Severus and his sons', Britannia 34 (2003), 268-271.

${ }^{74}$ R.P. Wright, 'Carpow and Caracalla', Britannia 5 (1974) 289-292, restoring imp. $e[t$ d.n. M. Aur. Antoninus piu $]$ s flelix...], dated the inscription to 212. Hence a further campaign by Caracalla in 212 has been inferred. But even if the restoration is correct, there could have been two further stones naming Severus and Geta.

75 Not discussed by B. Günnewig, Das Bild der Germanen und Britannier. Untersuchungen zur Sichtweise von fremden Völkern in antiker Literatur und moderner wissenschaftlicher Forschung (Frankfurt 1996), who does not go beyond the second century. On the ancient sources, 255ff., and their modern interpretation, 309ff., she argues justifiably enough that British scholars have ignored the 'aus der rhetorischen Tradition stammendes Element, welches den unzivilisierten Wilden dem kultivierten Bürger gegenübersetzt' (317). It need hardly be added that the northern peoples were far from primitive: see e.g. I. Armit, Towers in the North. The Brochs of Scotland (Stroud 2003).

${ }^{76}$ According to Frere 1987, op. cit. (n. 23) 161f., Severus' 'neglect to garrison the Lowlands [shows] that he was not intending a permanent occupation of Scotland.' Yet forts could have been garrisoned there later, had Caracalla not abandoned the conquests.

${ }_{77}$ Mommsen 1992, op. cit. (n. 1), 302.

${ }^{78}$ G. Alföldy, 'Nox dea fit lux! Caracallas Geburtstag', Historiae Augustae Colloquia, n.s. IV (1996), 9-36, convincingly argues that Caracalla was already back at Rome on 
The next governor, C. Julius Marcus, was appointed at latest by Caracalla in 212. His name is preserved on a milestone of 213 from near milecastle 17 on Hadrian's Wall. He was originally recorded on numerous other inscriptions in the frontier zone, but on most his name was deleted. At least eight dedications, some with no legible trace of Marcus' name surviving, were set up in honour of Caracalla or Julia Domna or both, with the same formula, pro pietate ac devotione communi. ${ }^{79}$ This unparalleled protestation of loyalty can readily be explained. The army of Britain had no doubt reacted unfavourably when the news of Geta's death, in late December $211,{ }^{80}$ reached it. This had been the case with II Parthica at Alba (HA, Vita Caracallae 2.7), which had probably been in Britain. When Caracalla wanted to kill Geta on the way back to Rome, he was prevented by the army, "for the soldiers felt great good will towards the younger brother, especially as he very closely resembled his father" (Cassius Dio 77[78].1.3). Herodian too says that Geta was more popular (4.3.2f.). At all events, Julius Marcus needed to affirm the army's and his own loyalty; he failed to convince and incurred damnatio.

Marcus' title leg(atus) Aug(usti) pr(o) pr(aetore) could have referred either to a consular governor of the undivided province or to a praetorian governor of Britannia Inferior. If his name may be restored on an inscription at London, that would show that he was governing - probably as the last to do so - a still undivided province. ${ }^{81}$ Caracalla then split Britain into two, the northerly Inferior having only one legion, VI Victrix. It may be inferred that, to justify the abandonment of the Scottish conquests, it was put about that the expedition's purpose had been punitive, and the reconstruction of Hadrian's Wall given as the real achievement: the Latin chroniclers, probably all deriving directly or indirectly from the Kaisergeschichte, name the building of the Wall as Severus' principal or only achievement in Britain, and know nothing of campaigns in Caledonia. ${ }^{82}$

his birthday, 4 April 211, as revealed by his re-interpretation of CIL VI 1080, now republished as VI 40638, with his commentary.

${ }_{79}$ Birley 2005, op. cit. (n. 5), 203-208.

${ }^{80}$ Geta was murdered in late December 211 : T.D. Barnes, 'Pre-Decian Acta martyrum', fThS 19 (1968), 509-531, at 523ff.

${ }^{81}$ RIB+add. 8; Birley 2005, op. cit. (n. 5), 206 and n. 62, 208.

${ }^{82}$ See A.R. Birley, 'Further notes on HA Severus', Historiae Augustae Colloquia, n.s. II (1994), 19-42, at 36ff. 